\title{
Fuzzy Analogical Gates Approach for Heat Exchangers Networks
}

\author{
M.H.Hussein \\ Teaching Assistant \\ Chemical \\ Engineering \\ Department - High \\ Institute of \\ Engineering \\ Shorouk City
}

\author{
H.Moselhy \\ Assistant Professor \\ Chemical \\ Engineering \\ Department - High \\ Institute of \\ Engineering \\ Shorouk City
}

\author{
S.Aly \\ Professor \\ Chemical and \\ Petroleum Refining \\ Engineering \\ Department - Suez \\ University
}

\author{
M. E. Awad \\ Assistant Professor \\ Chemical and \\ Petroleum Refining \\ Engineering \\ Department - Suez \\ University
}

\begin{abstract}
This paper presents a systematic method for synthesis of heat exchanger networks, the proposed algorithm consists of three sequential steps to select the optimal approach temperature: i) Estimation of normalized minimum approach temperature, normalized minimum hot utility and normalized minimum cold utility. ii) Fuzzy analogical gates network. iii) Selection of the best weight index. Two analogical gates (symmetric and asymmetric) are employed. The symmetric gate (AND gate) inputs are the normalized minimum approach temperature and normalized hot utility. The asymmetric gate (Invoke gate) inputs are the output of the AND gate and the normalized cold utility. The proposed method has been applied for four problems well-known in published literature. The results of these case studies show that the present strategy is both robust and accurate in finding out global optimum in comparison with previous works, characterized by its simplicity and can be implemented by hand calculations.
\end{abstract}

\section{Keywords}

Heat Exchanger Networks, Fuzzy Analogical Gates, Energy saving, Pinch Technology.

\section{INTRODUCTION}

HEN synthesis subject has been well-studied over the last 40 years. As a research theme, numerous papers have been published focusing distinct methods and techniques of synthesis. Heat recovery systems were always of interest in synthesis studies.

After the first energy crisis, during the 1970s, which can be considered as the driving force of the heat exchanger network synthesis study, as a research area, a considerable increase occurred in the number of papers related to the subject. Industries, universities and research centers had to find solutions to minimize the use of thermal energy from the burn of combustibles, like crude oil. Essentially, the HEN synthesis task consists of finding a practical sequence of equipment combining pairs of streams, in a way that the network is optimal in relation to the global cost. The great complexity of the problem is its combinatorial nature. For a fixed number of streams, there are a great number of possibilities of combinations. Nevertheless, the number of HEN configurations that satisfies the minimum utilities consumption is smaller than the total number of possible configurations [1].

According to Ravagnani et al. [2], several kinds of studies were done aiming to develop methodologies to obtain optimal
HEN to reach these goals. Research was concentrated in three important areas, Pinch Analysis, which uses thermodynamic concepts, Heuristics and Mathematical Programming, such as (LP), (NLP), (MILP), and (MINLP). Recently, heuristic methods of optimization have also been used to solve linear and non-linear models.

Gundersen [3] and Furman [1] published complete reviews on HEN synthesis. Important research lines have being proposed, like pinch analysis and mathematical programming.

Pinch Analysis uses thermodynamic concepts and heuristics, as can be seen in the works of Linnhoff and Flower [4], Linnhoff et al. [5, 6, and 7], Linnhoff [8, 9]. In mathematical programming the HEN synthesis is treated as an optimization problem. According to Grossmann et al. [10], a gradual evolution has occurred relative to mathematical programming method utilization, from the sequential approaches, where one aims to obtain the problem solution step by step, as can be seen in the papers of Cerda and Westerberg [11], Colberg and Morari [12], Floudas et al. [13], Gundersen and Grossmann [3] and Papoulias and Grossmann [14], till works using simultaneous optimization, where all of the variables are optimized simultaneously, as can be seen in the papers of Bjork and Westerlund [15], Ciric and Floudas [16], Quesada and Grossmann [17], Yee and Grossmann [18] and Zamora and Grossmann [19].

In this paper a new systematic method for synthesis of heat exchanger networks has been presented, the proposed algorithm consists of three sequential steps to select the optimal approach temperature, the results of case studies show that Fuzzy analogical gates strategy is both robust and accurate in finding out global optimum minimum approach temperature in comparison with previous works, which ensures its economic effectiveness.

\section{ANALOGICAL GATES}

Analogical gates are of two kinds Badreddin [20]: symmetric and asymmetric. These gates can be regarded as relations on the input set:

$$
\mathrm{S}=x \times y, x \in\left[x_{\max },-x_{\max }\right], y \alpha \quad\left[y_{\max },-y_{\max }\right], x, y \alpha \mathrm{R} .
$$

Symmetric gates perform operations similar to their logical counter parts such as union (OR), intersection (AND) and exclusion (XOR).They borrow their names from the analogy to Boolean logic-gates on the vertices of the first and third quadrant in the input space. 


\subsection{Symmetric Gates}

In the fuzzy analogical-AND gate as shown in Fig. 1(a), the output grows fastest when both inputs simultaneously grow. Also no output is produced if either input is zero.

The parameters $\mathrm{a}$ and $\mathrm{b}$ can be obtained by using the boundary conditions and zero derivative on the main axis. In this work the determined values of a, b are 2.28466 and - 0.089817, respectively.

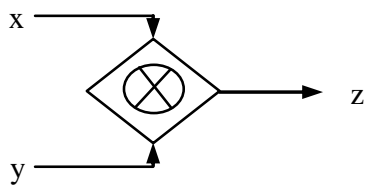

Fig .1(a) Symbols for the analogical (AND) gate.

$$
\begin{aligned}
& \mathrm{Z}=x \otimes y=x[1-\xi(y, x)]+y[1-\xi(x, y)] \\
& \xi(y, x)=e^{\left[-\frac{a y^{2}+b y x}{y^{2}+x^{2}}\right]}, \text { and } \mathrm{x}, \mathrm{y} \in \mathrm{R} \\
& \xi(x, y)=e^{\left[-\frac{a x^{2}+b x y}{x^{2}+y^{2}}\right]}, \text { and } \mathrm{x}, \mathrm{y} \in \mathrm{R}
\end{aligned}
$$

\subsection{Asymmetric Gates}

The invoke gate is characterized such that as the $\mathrm{x}$-input grows, the share of the y-input to the output increases. The absence of the $\mathrm{x}$-input inhibits the output. In the absence of the y-input, the $\mathrm{x}$-input is linearly passed to the output as shown in Fig.1 (b). In prevail gate the x-port is assigned an exceptional prevalence over the y-port. The latter is putthrough directly to the output as long as the former is absent. However, once the input is at the prevalent part it strongly dominates the output.

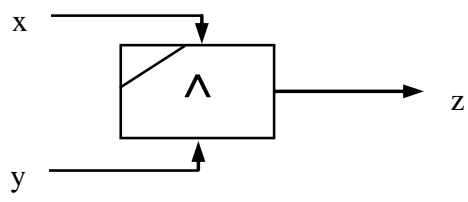

Fig.1 (b) Symbols for the analogical Invoke gate.

$$
\begin{aligned}
& \mathrm{Z}=x \wedge y=x \xi_{1}(y, x)+y\left[1-\xi_{2}(x, y)\right] \\
& \xi(y, x)=e^{\left[-\frac{a_{1} y^{2}+b_{1} y x}{y^{2}+x^{2}}\right]}, \text { and } \mathrm{x}, \mathrm{y} \in \mathrm{R} \\
& \xi(y, x)=e^{\left[-\frac{a_{2} x^{2}+b_{2} x y}{x^{2}+y^{2}}\right]}, \text { and } \mathrm{x}, \mathrm{y} \in \mathrm{R}
\end{aligned}
$$

Where: $\mathrm{a}_{1}=1.4749267, \mathrm{~b}_{1}=0.92870491$,

$$
\mathrm{a}_{2}=2.6317713, \mathrm{~b}_{2}=0.2287955 \text {. }
$$

\section{FUZZY ANALOGICAL GATES STRATEGY}

The algorithm followed in this step is selecting the best weight index as shown in Fig.2 which consists of three sequential steps:

i. Estimation of the normalized minimum approach temperature $\Delta \mathbf{T}$, normalized hot utility $\left(\mathbf{Q}_{\mathbf{H}}\right)_{\min }$ and normalized cold utility $\left(\mathbf{Q}_{\mathrm{C}}\right)_{\min }$.

ii. Fuzzy analogical gates network. iii. Selection of the best weight index.

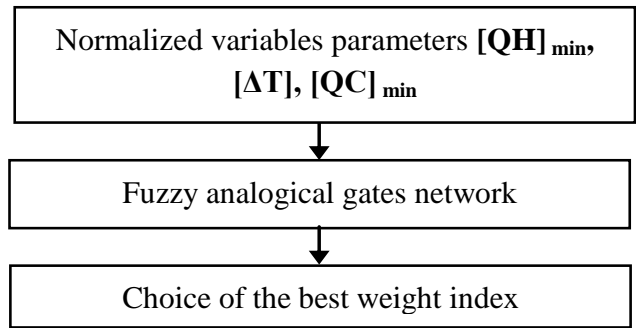

Fig.2. Fuzzy Analogical Gates Strategy

Most of the previous work Aly [21] shows that the synthesis of HEN mostly depends on the minimum heat load (hot and cold), minimum approach temperature difference. Accordingly, in this work these variables have been selected as inputs to the different fuzzy analogical gates.

\subsection{Normalized Variables Parameters}

Assume different values of minimum approach temperature, get the minimum heating $\left(\mathrm{Q}_{\mathrm{H}}\right)$ requirement $\&$ the minimum cooling $\left(\mathrm{Q}_{\mathrm{C}}\right)$ requirement from the cascade diagram according to Linnhoff, B., and Hindmarsh [7], for each value of $\Delta T$, $\left[\left(\mathrm{Q}_{\mathrm{H}}\right)_{\min },\left(\mathrm{Q}_{\mathrm{C}}\right)_{\min }\right]$ can be derived by application of a linear programming code, two bounds $(\boldsymbol{f})_{\min } \&(\boldsymbol{f})_{\max }$ can be computed, and the normalized variables can be estimated by:

$$
\begin{aligned}
& \mu=\frac{\left(f-f_{\text {max }}\right)}{\left(f_{\text {min }}-f_{\text {max }}\right)}, \text { Where } \\
& \mu=0 \text { If } f=f_{\text {max }} ; \mu=1 \text { If } f=f_{\text {min }}
\end{aligned}
$$

\subsection{Fuzzy Analogical Gates Network}

Two fuzzy analogical gates will be used sequentially as shown in Fig.3. The first gate is selected to be symmetric and the second gate is asymmetric. A fuzzy analogical - AND gate will be followed hv a fuzzy invoke gate

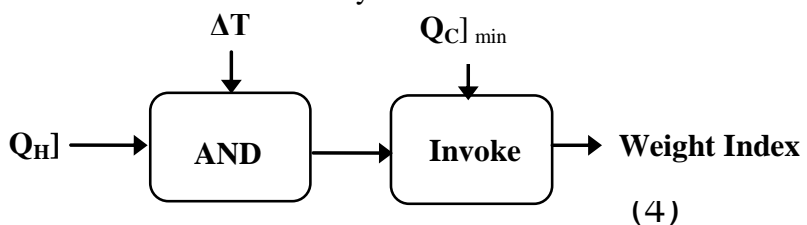

Fig.3. Fuzzy analogical gates network.

The symmetric gate inputs are the normalized heat load $(\mathrm{QH})_{\min }$ and the normalized temperature differehze $(\Delta \mathrm{T})$. The asymmetric gate inputs are the output of the symmetric gate and $\left(\mathrm{Q}_{\mathrm{C}}\right)_{\min }$.

\subsection{Choice of the Best Weight Index}

The final step corresponds to the choice of the best weight Index. The operation is carried out by comparing (W.I) values for all minimum approach temperature and by choosing the greatest one.

W.I ${ }_{\text {optimum }}=\max \left\{\mathrm{W} . \mathrm{I}_{1}, \mathrm{~W} . \mathrm{I}_{2}, \mathrm{~W} . \mathrm{I}_{3} \ldots ..\right\}$

\section{PROBLEM STATEMENT}

The HEN synthesis problem to be addressed in this paper can be stated as follows: A set of hot streams to be cooled and cold streams to be heated are given which include stream data with inlet and outlet stream temperatures, heat capacity flow 
rates and heat transfer coefficients. In addition, a set of hot and cold utilities are specified. The basic objective of the HENS problem is to synthesize a network of heat exchangers, which facilitate the desired heat exchange, while keeping the investment (exchanger area) and operating costs (utilities consumption) to a minimum value. Fuzzy analogical gates strategy is employed in the present work to select the optimal minimum approach temperature which accordingly leads to minimum total annual cost.

\section{EXAMPLES}

The proposed method will be tested using four case studies reported in the literature, for comparison.

\subsection{Example 1 (4SP1)}

This is the 4SP1 problem involving two hot and two cold streams, one cold utility and one hot utility stream taken from Shenoy [22]. The overall heat transfer coefficients for all matches are the same. The specifications for all streams, plant data are shown in table 1and 2. The example was solved by MINLP model, Supertarget method as shown in table 3, 4 and Fuzzy analogical gates method to minimize Total Annual Cost (TAC).

\subsection{Example 2}

This example is taken from Hall [23] involves five hot and four cold streams, one cold utility and one hot utility stream. The overall heat transfer coefficients for all matches are different. The specifications for all streams and plant data are shown in table 7 and 8.The example was solved by MINLP model, Supertarget and Fuzzy analogical gates method to minimize Total Annual Cost (TAC) at EMAT $=20^{\circ} \mathrm{C}$. The final optimum network is shown in Fig 5. The annual cost of hot utility and cold utility is $(\$ / \mathrm{Yr} 2,584,000)$. The area requirement is $9680 \mathrm{~m}^{2}$ and the total capital cost is $(\$ / \mathrm{Yr}$ $1,336,763)$.

\subsection{Example 3}

The popular Aromatics plant problem [24] is the subject for this case study. The problem involves finding a cost-optimal network of exchangers for four hot streams and five cold streams one cold utility (Water) and one hot utility stream (Hot Oil) having different heat transfer coefficients. The plant data and specifications of all streams for the aromatics problem are given in Table 11 and 12. The corresponding network structure is shown in Fig. 6. The network obtained in this work has the lowest cost among all the unsplit cases. However, the network obtained by Pettersson [25] using stream splitting has the lowest cost among all the reported solutions as shown in table 14 .

\subsection{Example 4}

This is a 10 stream problem studied first by Ahmed [26]. The problem involves finding a cost-optimal network of exchangers for six hot streams and four cold streams one cold utility and one hot utility stream having the same heat transfer coefficients. The input data for the problem is given in table 15 and 16. The final optimum network is shown in Fig 7. The

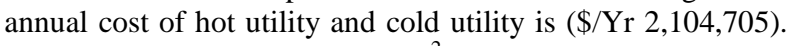
The area requirement is $55,513 \mathrm{~m}^{2}$ and the total capital cost is (\$/Yr 3,330,832). The solution obtained by the proposed method is lower than the solution produced by Supertarget, lower than the solution obtained by combination of Pinch \& Genetic algorithm and lower than the solution obtained by Differential Evolution Method.
Table 1: Stream and cost data for Example 1.

\begin{tabular}{cccccc}
\hline Stream & $\begin{array}{c}\mathrm{T}_{\text {in }} \\
\left({ }^{\circ} \mathrm{C}\right)\end{array}$ & $\begin{array}{c}\mathrm{T}_{\text {out }} \\
\left({ }^{\circ} \mathrm{C}\right)\end{array}$ & $\begin{array}{c}\mathrm{MCp} \\
\mathrm{kW} /{ }^{\circ} \mathrm{C}\end{array}$ & $\begin{array}{c}\mathrm{h} \\
\mathrm{kW} / \mathrm{m}^{2 \circ} \mathrm{C}\end{array}$ & $\begin{array}{c}\text { Metal } \\
\text { Specifications }\end{array}$ \\
\hline $\mathrm{H} 1$ & 175 & 45 & 10 & 0.2 & $\mathrm{SS}$ \\
$\mathrm{H} 2$ & 125 & 65 & 40 & 0.2 & $\mathrm{CS}$ \\
$\mathrm{C} 3$ & 20 & 155 & 20 & 0.2 & $\mathrm{SS}$ \\
$\mathrm{C} 4$ & 40 & 112 & 15 & 0.2 & $\mathrm{CS}$ \\
$\mathrm{HU}$ & 180 & 179 & - & 0.2 & $\mathrm{CS}$ \\
$\mathrm{CU}$ & 15 & 25 & - & 0.2 & $\mathrm{CS}$ \\
\hline
\end{tabular}

Table 2: Plant Data.

\begin{tabular}{|c|c|c|}
\hline Utility & Fuel gas cost & $120(\$ / \mathrm{kW} . \mathrm{yr})$ \\
\hline data & Cooling water cost & 10 (\$/kW.yr) \\
\hline Plant & Rate of interest (i) & $10 \%$ \\
\hline Data & Lifetime (n) & 5 years \\
\hline $\begin{array}{l}\text { Capital } \\
\text { cost data }\end{array}$ & $\begin{array}{l}A_{f} \text { : Annualization factor } \\
\text { Installed unit cost }\end{array}$ & $\begin{array}{l}(1+i)^{n} / n \\
30000+750(\mathrm{~A})^{0.81}\end{array}$ \\
\hline
\end{tabular}

Table 3: Results of HEN by using MINLP.

\begin{tabular}{cccc}
\hline Stream & Q $(\mathrm{kW})$ & Area $\left(\mathrm{m}^{2}\right)$ & $\begin{array}{c}\text { Materials of } \\
\text { Construction }\end{array}$ \\
\hline 1 & 460.735 & 171.534 & $\mathrm{SS} / \mathrm{SS}$ \\
2 & 519.265 & 202.273 & $\mathrm{CS} / \mathrm{SS}$ \\
3 & 1839.265 & 712.340 & $\mathrm{CS} / \mathrm{SS}$ \\
4 & 560.735 & 305.547 & $\mathrm{CS} / \mathrm{CS}$ \\
5 & 400 & 119.009 & $\mathrm{CS} / \mathrm{SS}$ \\
6 & 320 & 80.004 & $\mathrm{CS} / \mathrm{SS}$ \\
\hline Total & $\mathbf{4 1 0 0}$ & $\mathbf{1 5 9 0}$ & \\
\hline \multicolumn{5}{c}{} \\
Table 4: Results of HEN by using Supertarget. \\
\hline Stream & $\mathrm{Q}(\mathrm{kW})$ & Area $\left(\mathrm{m}^{2}\right)$ & Materials of \\
& 460.22 & 183 & Construction \\
\hline 1 & 639.8 & 377 & $\mathrm{SS} / \mathrm{SS}$ \\
2 & 1839.265 & 972 & $\mathrm{CS} / \mathrm{SS}$ \\
3 & 440.2 & 305.547 & $\mathrm{CS} / \mathrm{SS}$ \\
4 & 400 & 119.009 & $\mathrm{CS} / \mathrm{SS}$ \\
5 & 200 & 59 & $\mathrm{CS} / \mathrm{SS}$ \\
6 & 120 & 26 & CS/CS \\
7 & $\mathbf{4 1 0 0}$ & $\mathbf{2 0 4 1}$ & \\
\hline Total & & &
\end{tabular}

The summary of results of the proposed method is shown in table 5, which confirmed with results obtained, thus the optimum $\Delta \mathrm{T}=25^{\circ} \mathrm{C}$ which give a global cost of $(\$ / \mathrm{Yr}$ $287,875)$ and a weight index of $(0.611)$, which ensures our strategy.

Table 5. Results of Fuzzy Analogical gates.

\begin{tabular}{ccccc}
\hline $\boldsymbol{\Delta} \mathbf{T}\left({ }^{\circ} \mathbf{C}\right)$ & $\boldsymbol{\mu}_{\mathbf{1}}$ & $\boldsymbol{\mu}_{\mathbf{2}}$ & $\boldsymbol{\mu}_{\mathbf{3}}$ & W.I \\
\hline 15 & 0.375 & 0.926 & 0.926 & 0.327 \\
17.5 & 0.438 & 0.833 & 0.832 & 0.488 \\
20 & 0.500 & 0.741 & 0.739 & 0.599 \\
$\mathbf{2 5}$ & 0.625 & 0.556 & 0.553 & $\mathbf{0 . 6 1 1}$ \\
30 & 0.750 & 0.370 & 0.367 & 0.376 \\
35 & 0.875 & 0.185 & 0.181 & 0.093 \\
\hline
\end{tabular}

The final optimum network is shown in Fig 4. The annual cost of hot utility and cold utility is $(\$ / \mathrm{Yr} 100,600)$. The area requirement is $1886.8 \mathrm{~m}^{2}$ and the total capital cost is $(\$ / \mathrm{Yr}$ $287,875)$. The solution obtained by the proposed method is lower than the solution produced by MINLP and Supertarget method as shown in table 6 . 
Table 6: Comparison of results for Example 1.

\begin{tabular}{cccc}
\hline & $\begin{array}{c}\text { Shenoy } \\
{[\mathbf{2 2}]}\end{array}$ & $\begin{array}{c}\text { Hojjati } \\
{[\mathbf{2 8}]}\end{array}$ & $\begin{array}{c}\text { Present } \\
\text { Work }\end{array}$ \\
\hline Method & Supertarget & MINLP & A.G \\
$\boldsymbol{\Delta} \mathbf{T}\left({ }^{\circ} \mathbf{C}\right)$ & - & - & 25 \\
Hot Utility $(\mathbf{k W})$ & 400 & 400 & 780 \\
Cold Utility $(\mathbf{k W})$ & 320 & 320 & 700 \\
Total area $\left(\mathbf{m}^{\mathbf{2}}\right)$ & 2041 & 1590 & 1886.8 \\
Energy Cost $\mathbf{( \$ / Y r )}$ & 51,200 & 51,200 & 100,600 \\
Capital Cost $\mathbf{( \$ )}$ & $1,031,584$ & 851,602 & 581,600 \\
Global Cost $\mathbf{( \$ / y r )}$ & 383,475 & 325,502 & 287,875 \\
\hline
\end{tabular}

Table 7. Stream and cost data for Example 2.

\begin{tabular}{cccccc}
\hline Stream & $\begin{array}{c}\mathrm{T}_{\text {in }} \\
\left({ }^{\circ} \mathrm{C}\right)\end{array}$ & $\begin{array}{c}\mathrm{T}_{\text {out }} \\
\left({ }^{\circ} \mathrm{C}\right)\end{array}$ & $\begin{array}{c}\mathrm{MCp} \\
\mathrm{kW} /{ }^{\circ} \mathrm{C}\end{array}$ & $\begin{array}{c}\mathrm{h} \\
\mathrm{kW} / \mathrm{m}^{2 \circ} \mathrm{C}\end{array}$ & $\begin{array}{c}\text { Metal } \\
\text { Specifications }\end{array}$ \\
\hline $\mathrm{H} 1$ & 120 & 65 & 50 & 0.5 & $\mathrm{CS}$ \\
$\mathrm{H} 2$ & 80 & 50 & 300 & 0.25 & $\mathrm{CS}$ \\
$\mathrm{H} 3$ & 135 & 110 & 290 & 0.3 & $\mathrm{SS}$ \\
$\mathrm{H} 4$ & 220 & 95 & 20 & 0.18 & $\mathrm{SS}$ \\
$\mathrm{H} 5$ & 135 & 105 & 260 & 0.25 & $\mathrm{CS}$ \\
$\mathrm{C} 6$ & 65 & 90 & 150 & 0.27 & $\mathrm{SS}$ \\
$\mathrm{C} 7$ & 75 & 200 & 140 & 0.25 & $\mathrm{CS}$ \\
$\mathrm{C} 8$ & 30 & 210 & 100 & 0.15 & $\mathrm{CS}$ \\
$\mathrm{C} 9$ & 60 & 140 & 50 & 0.45 & $\mathrm{SS}$ \\
$\mathrm{HU}$ & 250 & 249 & - & 0.3 & $\mathrm{CS}$ \\
$\mathrm{CU}$ & 15 & 25 & - & 0.2 & $\mathrm{CS}$ \\
\hline
\end{tabular}

Table 8: Plant Data

\begin{tabular}{cll}
\hline Utility & Fuel gas cost & $120(\$ / \mathrm{kW} . \mathrm{yr})$ \\
data & Cooling water cost & $10(\$ / \mathrm{kW} . \mathrm{yr})$ \\
Plant & Rate of interest $(\mathrm{i})$ & $10 \%$ \\
Data & Lifetime $(\mathrm{n})$ & 5 years \\
Capital & Af : Annualization factor & $(1+\mathrm{i}) \mathrm{n} / \mathrm{n}$ \\
cost data & Installed unit cost $(\$)$ & $30000+750(\mathrm{~A}))^{0.81}$ \\
\hline
\end{tabular}

The summary of results of the proposed method is shown in table 9, which confirmed with results obtained, thus the optimum $\Delta \mathrm{T}=20^{\circ} \mathrm{C}$ which give a global cost of $(\$ / Y r 3,014,438)$ and a weight index of $(0.684)$.

Table 9: Results of Fuzzy Analogical gates.

\begin{tabular}{ccccc}
\hline $\boldsymbol{\Delta} \mathbf{T}$ & $\boldsymbol{\mu}_{\mathbf{1}}$ & $\boldsymbol{\mu}_{\mathbf{2}}$ & $\boldsymbol{\mu}_{\mathbf{3}}$ & W.I \\
\hline 17.5 & 0.500 & 1.000 & 1.000 & 0.539 \\
$\mathbf{2 0}$ & 0.571 & 0.874 & 0.874 & $\mathbf{0 . 6 8 4}$ \\
25 & 0.714 & 0.583 & 0.583 & 0.651 \\
27.5 & 0.786 & 0.437 & 0.437 & 0.466 \\
30 & 0.857 & 0.291 & 0.291 & 0.235 \\
\hline
\end{tabular}

The solution obtained by the proposed method is lower than the solution produced by MINLP and solution obtained by Supertarget method as shown in table 10.
Table 10: Comparison of results for Example 2.

\begin{tabular}{|c|c|c|c|c|}
\hline & $\begin{array}{l}\text { Hall } \\
{[23]} \\
\end{array}$ & $\begin{array}{c}\text { Jegede } \\
{[29]}\end{array}$ & $\begin{array}{c}\text { Hojjati } \\
{[28]} \\
\end{array}$ & $\begin{array}{c}\text { Present } \\
\text { Work } \\
\end{array}$ \\
\hline Method & $\begin{array}{c}\text { Super- } \\
\text { target }\end{array}$ & MINLP & MINLP & A.G \\
\hline$\Delta \mathrm{T}\left({ }^{\circ} \mathrm{C}\right)$ & 20 & 20 & 20 & 20 \\
\hline $\begin{array}{l}\text { Hot Utility } \\
(\mathbf{k W})\end{array}$ & 20950 & 20950 & 20950 & 20950 \\
\hline $\begin{array}{l}\text { Cold Utility } \\
\text { (kW) }\end{array}$ & 7000 & 7000 & 7000 & 7000 \\
\hline $\begin{array}{c}\text { Total area } \\
\left(\mathbf{m}^{2}\right)\end{array}$ & 9739 & 9659 & 9724 & 9680 \\
\hline $\begin{array}{c}\text { Energy Cost } \\
(\mathrm{M} \$ / \mathrm{Yr})\end{array}$ & 2.584 & 2.584 & 2.584 & 2.584 \\
\hline $\begin{array}{c}\text { Capital Cost } \\
(\mathrm{M} \$)\end{array}$ & 2.971 & 2.986 & 2.895 & $1, .336$ \\
\hline $\begin{array}{c}\begin{array}{c}\text { Global Cost } \\
(\mathrm{M} \$ / \mathbf{y r})\end{array} \\
\end{array}$ & 3.540 & 3.545 & 3.516 & 3.014 \\
\hline
\end{tabular}

Table 11. Stream and cost data for Example 3.

\begin{tabular}{ccccc}
\hline Stream & $\begin{array}{c}\mathrm{T} \text { in } \\
\left({ }^{\circ} \mathrm{C}\right)\end{array}$ & $\begin{array}{c}\text { Tout } \\
\left({ }^{\circ} \mathrm{C}\right)\end{array}$ & $\begin{array}{c}\mathrm{M} \mathrm{Cp} \\
\left(\mathrm{kW} /{ }^{\circ} \mathrm{K}\right)\end{array}$ & $\begin{array}{c}\mathrm{h} \\
\left(\mathrm{kW} / \mathrm{m}^{2}{ }^{\circ} \mathrm{K}\right)\end{array}$ \\
\hline $\mathrm{H} 1$ & 327 & 40 & 100 & 0.5 \\
$\mathrm{H} 2$ & 220 & 160 & 160 & 0.25 \\
$\mathrm{H} 3$ & 220 & 60 & 60 & 0.3 \\
$\mathrm{H} 4$ & 160 & 45 & 400 & 0.18 \\
$\mathrm{C} 1$ & 100 & 300 & 100 & 0.25 \\
$\mathrm{C} 2$ & 35 & 164 & 70 & 0.27 \\
$\mathrm{C} 3$ & 85 & 138 & 350 & 0.25 \\
$\mathrm{C} 4$ & 60 & 170 & 60 & 0.15 \\
$\mathrm{C} 5$ & 140 & 300 & 200 & 0.45 \\
Hot Oil & 330 & 250 & - & 0.3 \\
Water & 15 & 30 & - & 0.2 \\
\hline
\end{tabular}

Table 12: Plant Data

\begin{tabular}{cll} 
Utility & Fuel gas cost & $60(\mathrm{US} \$ / \mathrm{kW} . \mathrm{yr})$ \\
data & Cooling water cost & $6(\$ / \mathrm{kW} . \mathrm{yr})$ \\
Plant & Rate of interest (i) & $0 \%$ \\
$\begin{array}{c}\text { Data } \\
\text { Capital }\end{array}$ & Lifetime (n) & 5 years \\
cost data & Installed unit cost & $10,000+350 \mathrm{~A}(\$)$ \\
\hline
\end{tabular}

The summary of results of the proposed method is shown in table 13, which confirmed with results obtained, thus the optimum $\Delta \mathrm{T}=22.5^{\circ} \mathrm{C}$ with $\mathrm{TAC}(\$ / \mathrm{Yr} 2,944,998)$ and a weight index of (0.760).

Table 13: Results of Fuzzy Analogical gates.

\begin{tabular}{ccccc}
\hline $\boldsymbol{\Delta} \mathbf{T}$ & $\boldsymbol{\mu}_{\mathbf{1}}$ & $\boldsymbol{\mu}_{\mathbf{2}}$ & $\boldsymbol{\mu}_{\mathbf{3}}$ & $\mathbf{W . I}$ \\
\hline 20 & 0.571 & 1.000 & 1.000 & 0.663 \\
$\mathbf{2 2 . 5}$ & 0.643 & 0.833 & 0.833 & $\mathbf{0 . 7 6 0}$ \\
25 & 0.714 & 0.667 & 0.667 & 0.724 \\
30 & 0.857 & 0.333 & 0.333 & 0.296 \\
\hline
\end{tabular}

The network obtained in this work has the lowest cost among all the unsplit cases. However, the network obtained by Petterson [25] using stream splitting has the lowest cost among all the reported solutions as shown in table 14 . 
Table 14: Comparison of results for Example 3.

\begin{tabular}{|c|c|c|c|c|c|c|}
\hline 䓂 & 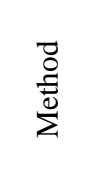 & 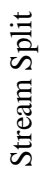 & 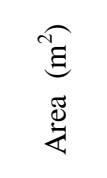 & 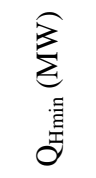 & 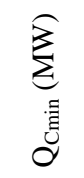 & 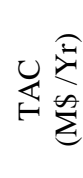 \\
\hline $\begin{array}{c}\text { Linnhoff } \\
\text { [30] } \\
\text { Zhu. }\end{array}$ & S.M & 0 & 17,400 & 25.31 & 33.03 & 2.960 \\
\hline $\begin{array}{c}\text { O' Neill } \\
\text { [31] }\end{array}$ & NLP & 2 & 16,630 & 26.22 & 33.94 & 2.970 \\
\hline $\begin{array}{c}\text { Zhu et al. } \\
\text { [31] }\end{array}$ & NLP & 0 & 16,380 & 26.83 & 34.55 & 2.980 \\
\hline $\begin{array}{c}\text { Lewin } \\
{[32]}\end{array}$ & GA & 2 & 17,050 & 25.09 & 32.81 & 2.936 \\
\hline $\begin{array}{l}\text { Lewin } \\
\text { [33] }\end{array}$ & GA & 0 & 16,880 & 25.69 & 33.41 & 2.946 \\
\hline $\begin{array}{c}\text { Petterson } \\
{[25]}\end{array}$ & SMR & 7 & 17,473 & 24.27 & 31.99 & 2.905 \\
\hline $\begin{array}{c}\text { Krishna } \\
{[34]}\end{array}$ & DEM & 0 & 16,536 & 25.88 & 33.60 & 2.942 \\
\hline $\begin{array}{c}\text { Azeez } \\
{[35]}\end{array}$ & STBS & 7 & - & - & - & 2.922 \\
\hline $\begin{array}{l}\text { Present } \\
\text { work }\end{array}$ & A.G & 0 & 15,360 & 23.08 & 30.80 & 2.945 \\
\hline
\end{tabular}

Table 15: Stream and cost data for Example 4.

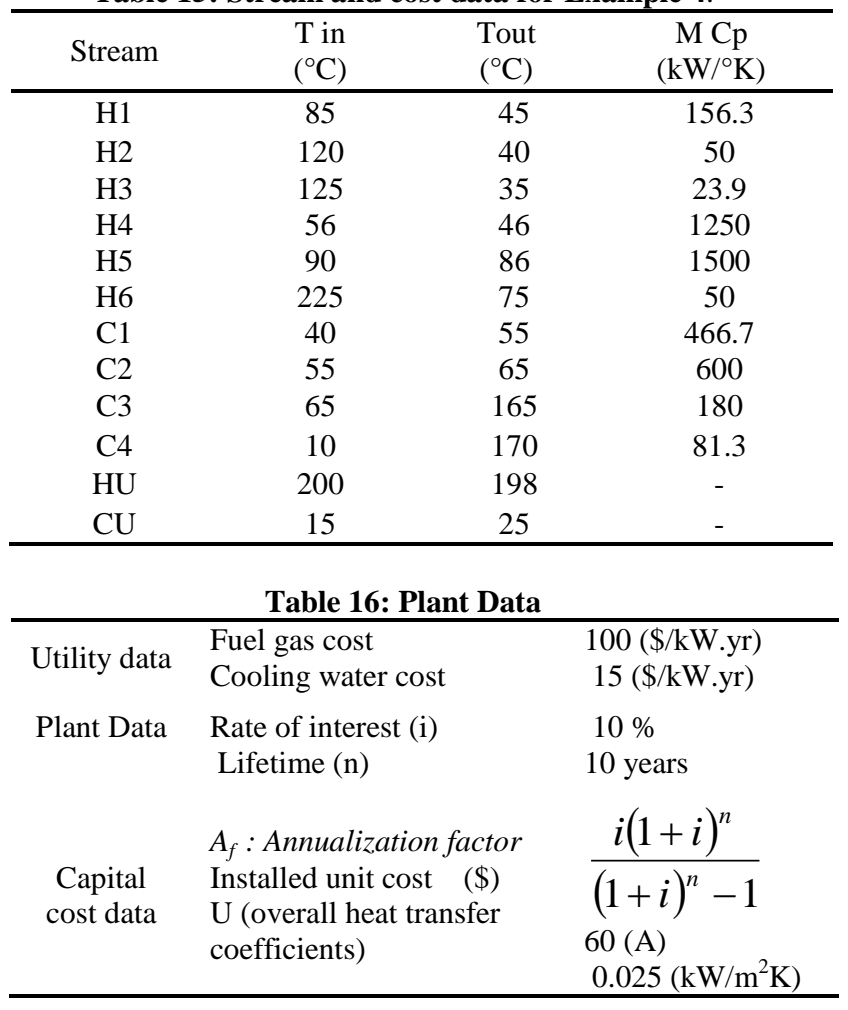

The summary of results of the proposed method is shown in table 17, which confirmed with results obtained, thus the optimum $\Delta \mathrm{T}=17.5^{\circ} \mathrm{C}$ with $\mathrm{TAC}(\$ / \mathrm{Yr} 2,647,630)$ and a weight index of (0.575), which ensures our strategy.

Table 17: Results of Fuzzy Analogical gates.

\begin{tabular}{|c|c|c|c|c|}
\hline$\Delta \mathbf{T}$ & $\mu_{1}$ & $\mu_{2}$ & $\mu_{3}$ & W.I \\
\hline 10 & 0.286 & 1.000 & 1.000 & 0.146 \\
\hline 12.5 & 0.357 & 0.845 & 0.845 & 0.328 \\
\hline 15 & 0.429 & 0.691 & 0.691 & 0.510 \\
\hline 17.5 & 0.500 & 0.590 & 0.590 & 0.575 \\
\hline 20 & 0.571 & 0.525 & 0.525 & 0.573 \\
\hline 25 & 0.714 & 0.395 & 0.395 & 0.420 \\
\hline 30 & 0.857 & 0.265 & 0.265 & 0.198 \\
\hline \multicolumn{5}{|c|}{ Table 18: Comparison of results of HEN } \\
\hline & $\begin{array}{c}\text { Ahmed } \\
{[26]}\end{array}$ & $\begin{array}{c}\text { Ravagnani } \\
{[33]}\end{array}$ & $\begin{array}{c}\text { Krishna } \\
{[19]}\end{array}$ & $\begin{array}{c}\text { This } \\
\text { Work }\end{array}$ \\
\hline Method & $\begin{array}{l}\text { Super } \\
\text { target }\end{array}$ & $\begin{array}{c}\text { Pinch + } \\
\text { (GA) }\end{array}$ & $(\mathrm{DEM})$ & A.G \\
\hline$\Delta \mathrm{T}\left({ }^{\circ} \mathrm{C}\right)$ & 10 & 24 & 19.46 & 17.5 \\
\hline $\begin{array}{l}\text { Hot Utility } \\
(\mathrm{kW})\end{array}$ & 15,400 & 20,529 & 20,745 & 19,033 \\
\hline $\begin{array}{l}\text { Cold Utility } \\
(\mathrm{kW})\end{array}$ & 9,796 & 14,923 & 15,139 & 13,427 \\
\hline $\begin{array}{l}\text { Total area } \\
\left(\mathrm{m}^{2}\right)\end{array}$ & - & 56,000 & 56,085 & 55,513 \\
\hline $\begin{array}{c}\text { Energy Cost } \\
(\mathrm{M} \$ / \mathrm{Yr})\end{array}$ & 1.686 & 2.276 & 2.301 & 2.104 \\
\hline $\begin{array}{c}\text { Capital Cost } \\
(\mathrm{M} \$)\end{array}$ & 5.387 & 3.396 & 3.365 & 3.330 \\
\hline $\begin{array}{c}\text { Global Cost } \\
(\mathrm{M} \$ / \mathrm{yr})\end{array}$ & 7.074 & 5.672 & 5.666 & 5.435 \\
\hline
\end{tabular}

The results of the DEM along with those of Ahmad [26] and Ravagnani et al. [27] are presented in Table 18. Ahmad [26] employed a fixed heat recovery approach temperature (HRAT) of $10 \circ \mathrm{C}$ for synthesizing his network and reported a network cost of $\$ 7,074,000$. Ravagnani et al. [27] have obtained a network costing $\$ 5,672,821$, for an 'optimized' HRAT of $24{ }^{\circ} \mathrm{C}$. Their work involved finding the optimal value for the minimum approach temperature using a combination of the pinch method and the Genetic Algorithm and subsequently synthesizing a cost-optimal as mentioned earlier, the DEM gives an optimal value for the minimum approach temperature (EMAT), during the simultaneous optimization of the network structure and other parameters. In this case study, it was found that the cost optimal network has a minimum approach temperature of $17.5^{\circ} \mathrm{C}$ by using Fuzzy Analogical gates method. 


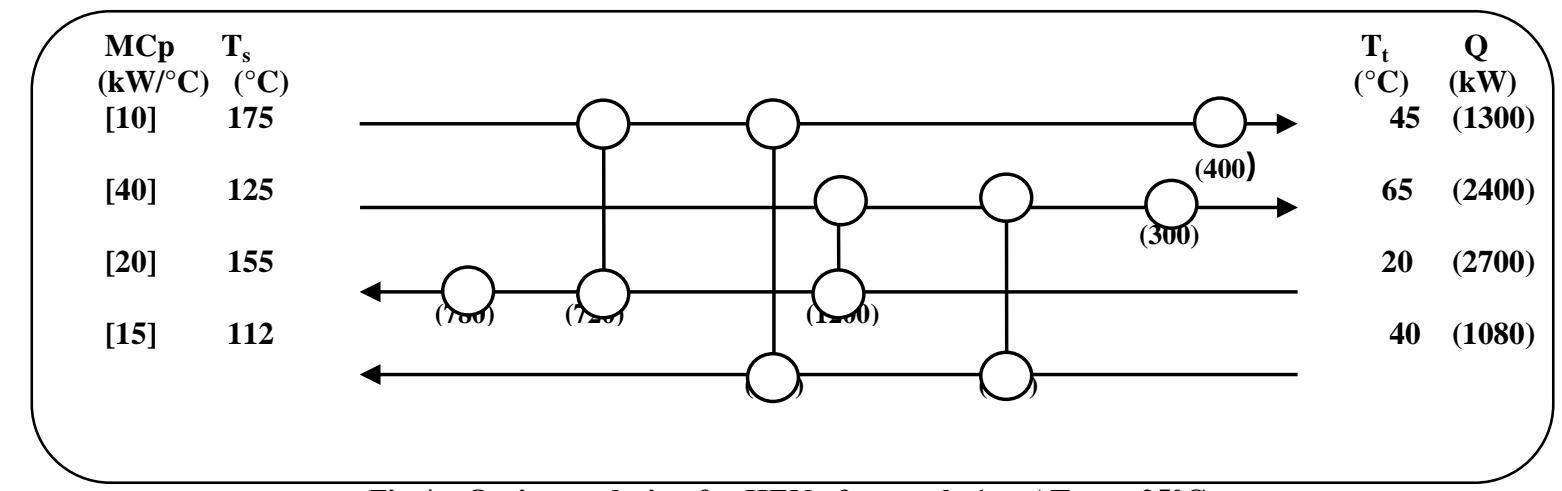

Fig.4. Optimum design for HEN of example 1 at $\Delta T_{\min }=25^{\circ} \mathrm{C}$

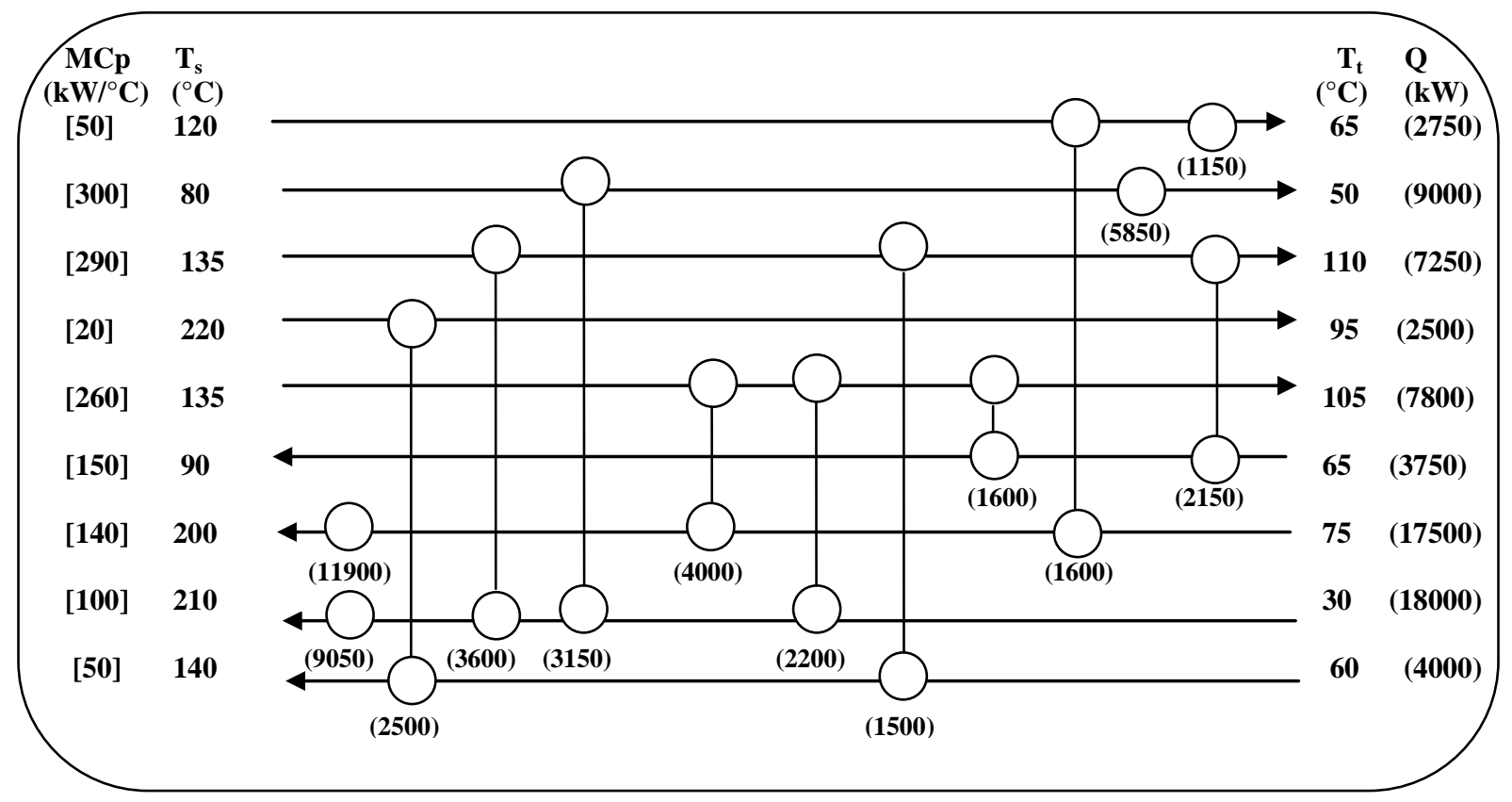

Fig.5. Optimum design for HEN of example 2 at $\Delta T_{\min }=20^{\circ} \mathrm{C}$

$\operatorname{MCp} \mathbf{T}_{\mathrm{s}}$

$\left(\mathrm{kW} /{ }^{\circ} \mathrm{C}\right)\left({ }^{\circ} \mathrm{C}\right)$

[100] 327

[160] 220

[60] 220

[400] 160

[100] 300

[70] 164

[350] 138

[60] 170

[200] 300

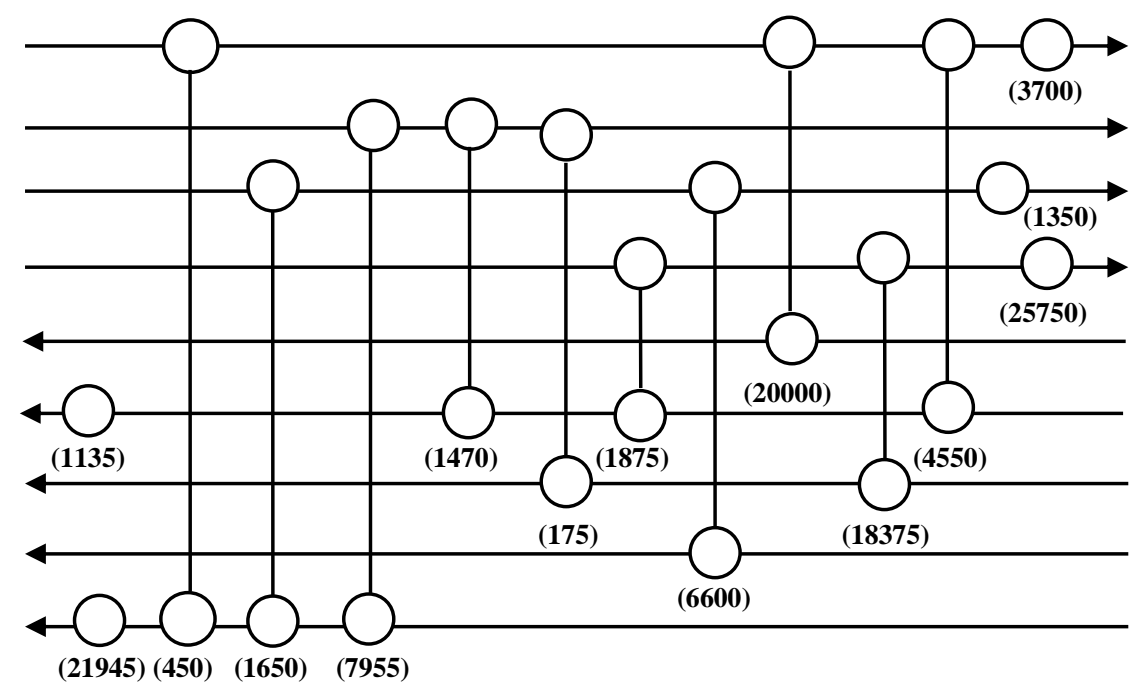

$\left({ }^{\circ} \mathrm{C}\right) \quad(\mathrm{kW})$

40 (28700)

160 (9600)

$60 \quad(9600)$

$45 \quad$ (46000)

100 (20000)

35 (9030)

85 (18550)

$60 \quad(6600)$

140 (32000)

Fig.6. Optimum design for HEN of example 3 at $\Delta T_{\min }=22.5^{\circ} \mathrm{C}$ 


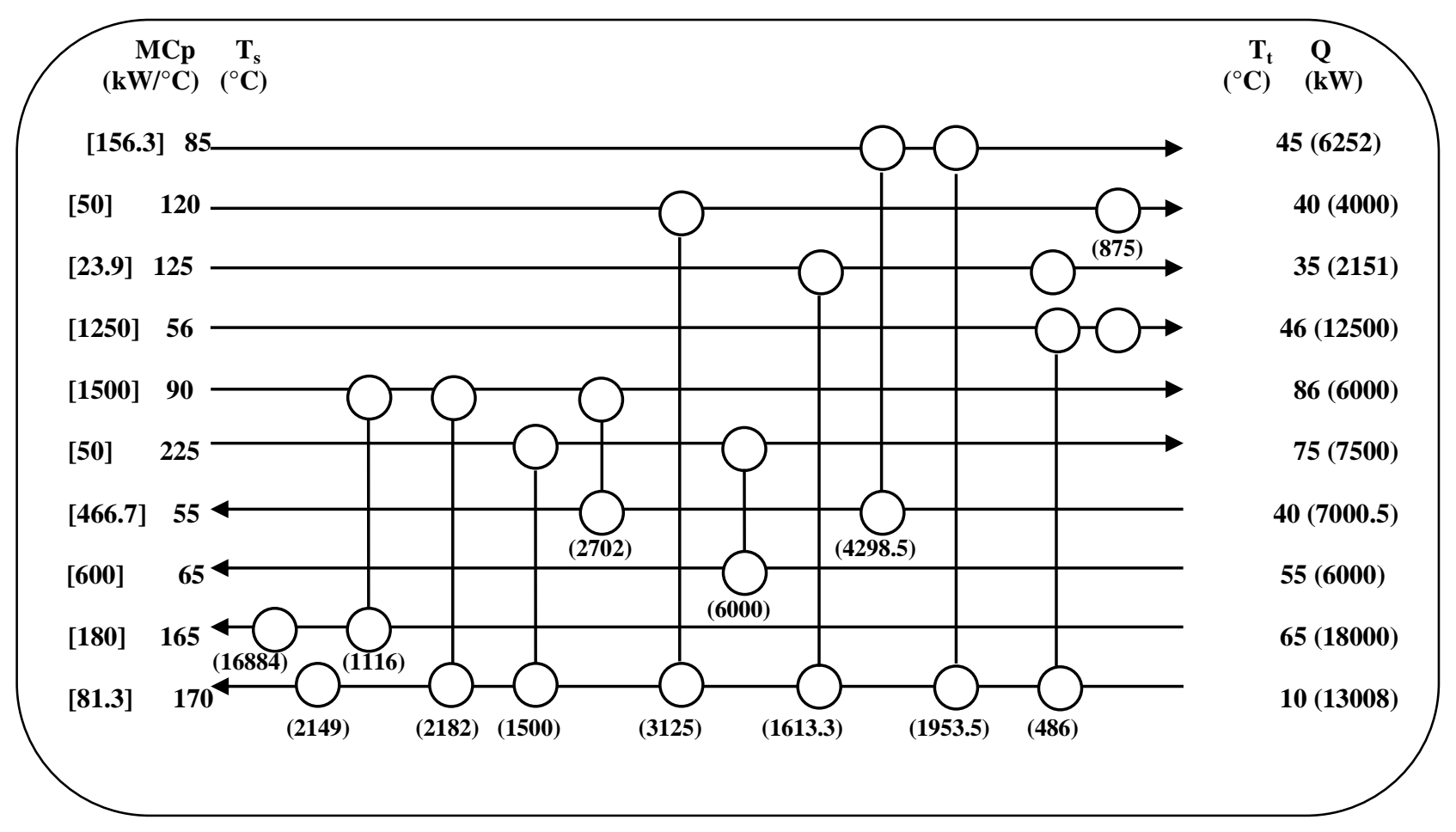

Fig.7. Optimum design for HEN at $\Delta T_{\min }=17.5^{\circ} \mathrm{C}$

\section{CONCLUSIONS}

The present study explores new systematic method for synthesis heat exchanger network. The proposed method when applied to problems previously reported in the literature yielded optimum solutions which are consistent with different approach. It is evident that the performance of the Fuzzy analogical gates is quite encouraging, characterized by its simplicity and can be implemented by hand calculations.

The results of case studies show that the present strategy is both robust and accurate in finding out global optimum cost \& optimum minimum approach temperature in comparison with previous works, which ensures its economic effectiveness,

\section{Nomenclature}

$\begin{array}{ll}\text { HENS } & \text { Heat Exchanger Networks } \\ \text { LP } & \text { Linear Programming } \\ \text { NLP } & \text { Non Linear Programming } \\ \text { MILP } & \text { Mixed Integer Linear Programming } \\ \text { MINLP } & \text { Mixed Integer Non Linear Programming } \\ \text { SS } & \text { Stainless Steel } \\ \text { CS } & \text { Carbon Steel } \\ \text { W.I } & \text { Weight Index } \\ \text { TAC } & \text { Total Annualized Cost } \\ \text { EMAT } & \text { Exchanger Minimum Approach } \\ & \text { Temperature } \\ \text { HRAT } & \text { Heat Recovery Approach Temperature } \\ \text { SMR } & \text { Sequential match reduction } \\ \text { STBS } & \text { Supply and Target Based Superstructure } \\ \text { A.G } & \text { Analogical Gates } \\ \text { GA } & \text { Genetic Algorithm. } \\ \text { DEM } & \text { Differential Evolution Method. } \\ \text { S.M } & \text { Simple Model } \\ \mu_{1} & \text { Normalized Minimum Approach } \\ & \text { Temperature }\end{array}$

$\begin{array}{ll}\mu_{2} & \text { Normalized Minimum Hot Utility } \\ & \text { Requirement } \\ \mu_{3} & \begin{array}{l}\text { Normalized Minimum cold Utility } \\ \text { Requirement }\end{array}\end{array}$

\section{REFERENCES}

[1] Furman, K. C., and Sahinidis, N. V. "A critical review and annotated bibliography for heat exchanger network synthesis in the $20^{\text {th }}$ century". Industrial and Engineering Chemistry Research, 41, (2335-2370), 2002.

[2] Ravagnani, M. A. S. S., Silva, A. P., and Andrade, A. L. "Detailed equipment design in heat exchanger networks synthesis and optimization". Applied Thermal Analysis, Issue 23, (141-151), 2003.

[3] Gundersen, T., and Grossmann, I. E. "Improved optimization strategies for automated heat exchanger network synthesis through physical insights". Comput. Chem. Eng., 14, (925-934), 1990.

[4] Linnhoff, B., and Flower, J. "Synthesis of heat exchanger networks. I, Systematic generation of energy optimal networks". AIChE Journal, 244, (633-642), 1978.

[5] Linnhoff, B., Mason, D. R., and Wardle, I. "Understanding heat exchanger networks". Comput. Chem. Eng. ,3, (295-302), 1979.

[6] Linnhoff, B., Towsend, D.W., Boland, D., Hewitt, G. F., Thomas, B. E. A., Guy, A. R., and Marsland, R. H. "A user guide on process integration for the efficient use of energy". UK: The Institute of Chemical Engineers. 1982. (I edition)

[7] Linnhoff, B., and Hindmarsh, E. "The pinch design method for heat exchanger networks". Chemical Engineering Science, 38, (745-763), 1983. 
[8] Linnhoff, B. "Pinch analysis: A state-of-the-art overview". Transactions of the IChemE, 71Part A, (503522), 1993

[9] Linnhoff, B. "Use pinch analysis to knock down capital costs and emissions". Chemical Engineering Progress, (32-57). 1994

[10] Grossmann, I. E., Caballero, J. A., and Yeomans, H. "Advances in mathematical programming for the synthesis of process systems". Latin American Applied Research, 30,(263-284), 2000.

[11] Cerda, J., and Westerberg, A. W. "Synthesizing heat exchanger networks having restricted stream/stream matches using transportation problem formulation". Chemical Engineering Science, 38, (1723-1730), 1983.

[12] Colberg, R. D., and Morari, M. "Area and capital cost targets for heat exchanger network synthesis with constrained matches and unequal heat transfer coefficients". Comput. Chem. Eng.14, (17-23), 1990.

[13] Floudas, C. A., Ciric, A. R., and Grossmann, I. E. "Automatic synthesis of optimum heat exchanger network configurations". AIChE Journal, 32, (276-286), 1986.

[14] Papoulias, S. A., and Grossmann, I. E. "structural optimizations approach in process synthesis. Part II. Heat recovery networks". Comput. Chem. Eng., 7, (707-716), 1983.

[15] Bjork, K., and Westerlund, T. "Global optimization for heat exchanger network synthesis problems with and without the isothermal mixing assumption". Comput. Chem. Eng., 26, (1581-1593), 2002.

[16] Ciric, A. R., and Floudas, C. A. "Heat exchanger network synthesis without decomposition". Comput. Chem. Eng., 15, 385-396. 1991.

[17] Quesada, I. E., and Grossmann, I. E. "Global optimization algorithm for heat exchanger networks". Industrial Engineering Chemistry Research, 32, 487. 1993.

[18] Yee, T. F., and Grossmann, I. E. "Simultaneous optimization models for heat integration. II. Heat exchanger network synthesis". Comput. Chem. Eng., 14, 1165. 1990

[19] Zamora, J., and Grossmann, I. E. "A global optimization algorithm for the synthesis of heat exchanger networks with no stream splits". Comput. Chem. Eng., 22, 367384. 1998.

[20] Badreddin E., "Fuzzy relations for behavior-fusion of mobile robots"., Proc. IEEE conf. on Robotics and Automation, San Diego, California,(1994), pp. 8-13.

[21] Aly S., "Fuzzy analogical gates for separation sequence synthesis". Chem. Eng. Proc, 36 (1997) 209-217.

[22] Shenoy, U.V.,'Heat Exchanger Network Synthesis' Process Optimization by Energy and Resource Analysis. Gulf Publishing Company Houston, Texas.
[23] Hall S.G., Ahmed S. and Smith R., Capital Cost Targets for Heat Exchangers Networks Comprising Mixed Materials of Construction, Pressure Ratings and Exchangers Types, Computers Chem. Engng.,14,319 (1990)

[24] Ian.C. Kemp., 'Pinch Analysis and Process integration A user guide on process integration for the efficient use of energy"' (2007)., (II edition) British Library.

[25] Pettersson, F. (2005). Synthesis of large-scale heat exchanger networks using a sequential match reduction approach. Computers \& Chemical Engineering, 29(5), 993-1007.

[26] Ahmad, S. (1985). Heat exchanger networks: Cost tradeoffs in energy and capital. Ph.D. Thesis. UK: UMIST Manchester.

[27] Ravagnani, M. A. S. S., Silva, A. P., Arroyo, P. A., \& Constantino, A. A. (2005). Heat exchanger network synthesis and optimisation using Genetic Algorithm. Applied Thermal Engineering, 25, 1003-1017.

[28] Hojjati, Mahmoud Reza and Omidkhah,Mohammad Reza,.' Cost Effective Heat Exchanger Network Design with Mixed Materials of Construction" Iran.J.Chem.\& Chem.Eng. vol.23,No.2,2004

[29] Jegede,F.O., Polley, G.T., 'Capital Cost Targets for Networks with non-uniform Heat Exchanger Specifications"' Comput. Chem. Eng., 16, (5), 477 (1992).

[30] Linnhoff, B., \& Ahmad, S. (1990). Cost optimum heat exchanger networks. 1. Minimum energy and capital using simple models for capital cost. Computers \& Chemical Engineering, 14(7), 729-750

[31] Zhu, X. X., O’Neill, B. K., Roach, J. R., \& Wood, R. M. (1995). A method for automated heat exchanger synthesis using block decomposition and non-linear optimization. Chemical Engineering Research \& Design Part A, 73(11), 919-930.

[32] Lewin, D. R. (1998). A Generalized method for HEN synthesis using stochastic optimisation. II. The synthesis of cost-optimal networks. Computers \& Chemical Engineering, 22(10), 1387-1405.

[33] Lewin, D. R., Wang, H., \& Shalev, O. (1998). A Generalized method for HEN synthesis using stochastic optimization. I. General framework and MER optima synthesis. Computers\&Chemical Engineering, 22(10), 1503-1513.

[34] Krishna M. Yerramsetty , C.V.S. Murty , Synthesis of cost-optimal heat exchanger networks using differentia evolution, Computers and Chemical Engineering 32 (2008) 1861-1876

[35] Azeez O.S , Isafiade A.J.,.Fraser D.M., 'Supply and Target based superstructure synthesis of heat and mass exchanger networks". Chemical Engineering Research \& Design Part A, $90 \quad$ (2012), $266 \quad$ - 287 